\title{
Comparison between effectivity of povidone lodin $1 \%$ application with swab technique and rinse to the number of bacteria colonization as an aseptic action in the Department of Oral and Maxillofacial Surgery, Faculty of Dentistry, Universitas Sumatera Utara
}

\author{
Isnandar, ${ }^{*}$ Hendry Rusdy, Indra B. Siregar, Nur Syamimi
}

\section{Abstract}

Objective: To compare between effectivity of povidone iodin $1 \%$ application with swab technique and rinse to the number of bacteria colonization as an aseptic action at the Department of Oral Surgery, Faculty of Dentistry, Universitas Sumatera Utara.

Material and Methods: This was an experimental study with posttest only control group design approach. Purposive technique is applied to collect samples which are clinical students. In this study, sample were divided into 4 groups and each consisting of 10 people. The sample was divided into negative control group with $0.9 \%$ normal saline and $1 \%$ povidone iodine treatment group with two techniques which is swab and gargle.

Results: Based on Mann-Whitney test result on 1\% Povidone lodin group which was rinse and swab technique obtained $p$-value $=0.382$ where $p$-value $>0.05$ so it can be concluded that there is no significant difference between $1 \%$ Povidone lodine in rinsing technique and $1 \%$ Povidone lodine in swabbing.

Conclusion: Rinsing was more effective than swab as an aseptic action with $1 \%$ Povidone lodine.
Department of Oral and Maxillofacial Surgery, Faculty of Dentistry, Universitas Sumatera Utara, Medan, Indonesia
*Correspondence to: Isnandar, Department of Oral and Maxillofacial Surgery, Faculty of Dentistry, Universitas Sumatera Utara, Medan, Indonesia

isnandar@usu.ac.id

Received: 5 December 2018 Revised: 15 February 2019 Accepted: 19 April 2019 Available Online: 1 August 2020

Keywords: Asepsis action swab, Bacteria colonization, Rinsing, 1\% povidone iodine

Cite this Article: Isnandar, Rusdy H, Siregar IB, Syamimi N. 2020. Comparison between effectivity of povidone lodin 1\% application with swab technique and rinse to the number of bacteria colonization as an aseptic action in the Department of Oral and Maxillofacial Surgery, Faculty of Dentistry, Universitas Sumatera Utara. Journal of Dentomaxillofacial Science 5(2): 90-93. D0I: 10.15562/jdmfs.v5i2.848

\section{Introduction}

Dentists cannot be separated from the possibility to contact directly or indirectly with microorganisms in the patient's oral cavity, so that infection control is needed in various treatment measures in the field of dentistry. ${ }^{1}$ When asepsis is not carried out properly, it allows infection. The risk of infection is increased in intraoral surgical procedures because it is not possible to achieve aseptic conditions if the number of bacteria flora normal in the mouth is increase. ${ }^{2}$

Mouthwash is a solution or liquid that is used to help provide freshness in the oral cavity and cleanse the oral cavity from plaques and organisms that cause diseases in the oral cavity. Povidone iodine is one of the antiseptic substances that is often used in asepsis. This mouthwash is effective in reducing plaque, gingivitis and is also used for routine oral hygiene procedures. ${ }^{3}$ It is very difficult to achieve aseptic conditions in the oral cavity, due to the large number of bacteria in the mouth. When applying antimicrobial agents, two broad techniques are generally used which is mouth rinse and swabbing. ${ }^{4}$

The oral swab technique covers the entire oral cavity, teeth, the soft tissue of the mouth including the buccal mucosa, vestibule, gingiva and floor of the mouth and the dorsum of the tongue. ${ }^{5}$ Mouth rinse may be better than swabbing in oral decontamination, because swabbing does not achieve cleanliness of the lingual, occlusal, and interproximal surfaces. Furthermore, Axelsson and Lindhe found that rinse with antiseptic mouthwash after brushing increases the proportion of plaque-free surfaces from $58 \%$ to $93 \%$, and effectively decreases plaque in areas not covered by brushing. It has been suggested that the mucosal surface may act as a reservoir for bacteria, which can then recolonize bacteria after dental prophylaxis. ${ }^{4}$

\section{Material and Methods}

This was an experimental study with post-test only control group design approach. The non probability sampling with purposive technique is applied to collect samples which are clinical students at Department of Oral and Maxillofacial Surgery in Faculty of Dentistry, Universitas Sumatera Utara. In this study, sample were divided into 4 groups and each consisting of 10 people.

Normal Saline $0.9 \%$ used as control group while Povidone Iodine $1 \%$ was used as the treatment 
group. The participants were randomly allocated into four groups. There were group rinsed with $15 \mathrm{ml}$ of $0.9 \%$ normal saline and $1 \%$ Povidone Iodine for $30 \mathrm{~s}$, whereas the other group had their mouths swabbed with a gauze swab soaked in $0.9 \%$ normal saline and $1 \%$ Povidone Iodine. ${ }^{4}$ All the participants for swab with control group and treatment group, the research subject was seated in the dental unit. Soak sterile gauze in $0.9 \%$ normal saline and $1 \%$ Povidone Iodine in a plastic cup. Swab subject's oral cavity starting from the direction of the buccal surface of tooth 17 to the buccal part of tooth 27. After that, continue swab from the buccal surface of tooth 37 to the buccal surface of tooth 47 . In this case, the swab includes the gingival and buccal mucosa of the upper and lower jaw. The same gauze is used for swab from the lingual surface of teeth 47 to the lingual surface of teeth 37 , then swab palatal surface 27 of the tooth to the palatal part of tooth 17 . In this case, the swab includes the lingual and palatal floor of the mouth and gingiva. Swab on the dorsal part of the tongue. ${ }^{5}$ The results of the swab gauze are inserted into a sterile storage tube.

The samples were then sent to the microbiology laboratory for bacterial cultivation on the plate count agar and incubated for 24 hours. ${ }^{6,7}$ The number of bacterial colonies grown were then counted using Colony Counter. Data processing was done with computer analyzed using MannWhitney test.

\section{Results}

Table 1 showed the number of bacterial colonies in the control group sample and the $1 \%$ povidone iodine group with Swab technique and rinsing technique. The mean result obtained for rinse with control group $0.9 \%$ normal saline was $37.1 \pm$ $5.008 \mathrm{CFU} / \mathrm{ml}$, for rinse with treatment group $1 \%$ Povidone Iodine was $9.4 \pm 2.668 \mathrm{CFU} / \mathrm{ml}$, for swab with control group was $81.4 \pm 17.876 \mathrm{CFU} / \mathrm{ml}$ and for swab with $1 \%$ Povidone Iodine was $15.8 \pm$ $4.666 \mathrm{CFU} / \mathrm{ml}$. Table 2.

The statistic test between the four groups were analyzed using Mann- Whitney test and the p value $=0.001<0.05$. Table 3 This results showed that there was a significant differences in the number of bacterial colonies between the control groups and treatment group of swab technique. Based on the Mann-Whitney test results in the control group and the treatment group of rinsing technique obtained $\mathrm{p}=0.001$ where the $\mathrm{p}$-value $<0.05$ so it can be concluded that there was a significant difference between both group. Table 4 .

Further test between two groups were analyzed using Mann-Whitney test. Based on the results of the Mann-Whitney test in the $1 \%$ Povidon Iodin group that was rinsed and swab obtained $\mathrm{p}=0.382$ where the p-value $>0.05$ so it can be concluded that there was no significant difference between the $1 \%$ povidone iodine group rinsed and $1 \%$ Povidon Iodine group swabed table 5.

\section{Discussion}

The results showed that there was a significant decrease in the number of bacterial colonies in the control group and $1 \%$ povidone iodine group with swab technique $(\mathrm{p}<0.05)$. This is because Povidone iodine $1 \%$ has anti-bacterial properties mainly through a mechanism by which povidone carries free iodine compounds into the cell membrane. The use of $0.9 \% \mathrm{NaCl}$ as a control group was caused by

Table 1 The number of bacterial colonies in the control group sample and the $1 \%$ povidone iodine group with Swab technique and rinsing technique

\begin{tabular}{|c|c|c|c|c|}
\hline \multirow[b]{2}{*}{ No Sample } & \multicolumn{4}{|c|}{ Total Bacterial Colonies (CFU/mL) } \\
\hline & $\begin{array}{c}\text { Control group with swab } \\
\text { technique }\end{array}$ & $\begin{array}{c}1 \% \text { Povidone lodine group } \\
\text { with swab technique }\end{array}$ & $\begin{array}{c}\text { Control group with rinse } \\
\text { technique }\end{array}$ & $\begin{array}{c}1 \% \text { Povidone lodine group } \\
\text { with rinse technique }\end{array}$ \\
\hline 1 & 30 & 14 & 80 & 8 \\
\hline 2 & 68 & 10 & 50 & 4 \\
\hline 3 & 25 & 6 & 45 & 8 \\
\hline 4 & 63 & 11 & 32 & 9 \\
\hline 5 & 21 & 5 & 136 & 3 \\
\hline 6 & 209 & 47 & 30 & 7 \\
\hline 7 & 40 & 8 & 29 & 12 \\
\hline 8 & 100 & 10 & 70 & 25 \\
\hline 9 & 47 & 34 & 19 & 8 \\
\hline 10 & 72 & 25 & 19 & 3 \\
\hline
\end{tabular}


Table 2 Data normality test results

\begin{tabular}{llc}
\hline Group & $\mathbf{n}$ & p-value \\
\hline Control group (normal saline 0.9\%) with swab technique & 10 & 0.146 \\
1\% Povidone Iodine group with swab technique & 10 & 0.021 \\
Control group (normal saline 0.9\%) with rinse technique & 10 & 0.259 \\
$1 \%$ Povidone Iodine group with rinse technique & 10 & 0.001 \\
\hline
\end{tabular}

Table 3 Data analysis using Mann-Whitney test

\begin{tabular}{lccc}
\hline Group & $\begin{array}{c}\text { Mean of total bacteria count } \\
\text { (mean } \pm \text { SD) }\end{array}$ & $\mathbf{n}$ & p-value \\
\hline $\begin{array}{l}\text { Control group (normal saline 0.9\%) with swab } \\
\text { technique }\end{array}$ & $81.4 \pm 17.876 \mathrm{CFU} / \mathrm{ml}$ & 10 & 0.001 \\
$1 \%$ Povidone Iodine group with swab technique & $15.8 \pm 4.666 \mathrm{CFU} / \mathrm{ml}$ & 10 & \\
\hline
\end{tabular}

Table 4 Data analysis using Mann-Whitney test

\begin{tabular}{lccc}
\hline Group & $\begin{array}{c}\text { Mean of total bacteria count } \\
\text { (mean } \pm \text { SD) }\end{array}$ & n & p-value \\
\hline $\begin{array}{l}\text { Control group (normal saline 0.9\%) with rinse } \\
\text { technique }\end{array}$ & $37.1 \pm 5.008 \mathrm{CFU} / \mathrm{ml}$ & 10 & 0.001 \\
$1 \%$ Povidone Iodine group with rinse technique & $9.4 \pm 2.668 \mathrm{CFU} / \mathrm{ml}$ & 10 & \\
\hline
\end{tabular}

Table 5 Data analysis using Mann-Whitney test

\begin{tabular}{|c|c|c|c|}
\hline Group & $\begin{array}{l}\text { Mean of total bacteria count } \\
\text { (mean } \pm \text { SD) }\end{array}$ & $\mathbf{n}$ & p-value \\
\hline $\begin{array}{l}1 \% \text { Povidone Iodine group with swab } \\
\text { technique }\end{array}$ & $15.8 \pm 4.666 \mathrm{CFU} / \mathrm{ml}$ & 10 & \multirow{2}{*}{0.382} \\
\hline $\begin{array}{l}1 \% \text { Povidone Iodine group with rinse } \\
\text { technique }\end{array}$ & $9.4 \pm 2.668 \mathrm{CFU} / \mathrm{ml}$ & 10 & \\
\hline
\end{tabular}

normal saline which would not reduce the number of intraoral bacteria which proved to have no antiseptic properties and could not be recommended for preoperative oral cavity decontamination. ${ }^{2}$

From the results of the statistical test it was concluded that there were significant differences in the number of bacterial colonies between the control group and the $1 \%$ povidone iodine group with the rinsing technique. This is because the rinsing technique can reach areas in the oral cavity that are hard to reach such as tooth cracks. ${ }^{4}$

In table 1 there are variations in the number of bacterial colonies in the control group using swab techniques on number $7,9,10$, control group with a rinsing technique on number 3 and 5 , and $1 \%$ povidone iodine group number 7 and 8 . This is likely due to different bacterial oral cavity factors in the oral cavity for each individual so it causes the varied results. ${ }^{8}$

The number of bacterial colonies in table 1 shows that bacteria found in the control group with swab technique were higher than bacteria in the control group with a rinse technique. This is related to the rinsing power which kill bacteria in the oral cavity. In addition, the use of $0.9 \% \mathrm{NaCl}$ which is also capable of killing the bacteria in small amounts due to its hypertonic condition. Therefore, the factor of $0.9 \%$ use of normal saline as a control group also affected the final results found in the swab and rinse of control group., ${ }^{2,9}$

\section{Conclusion}

From the results of the discussion above, it can be concluded that povidone Iodine $1 \%$ antiseptic mouthwash helps both techniques together with rinsing or swab in reducing the number of bacterial colonies in the oral cavity. Although the results between rinsing and swab with $1 \%$ povidone iodine have insignificant results, the mean number of bacterial colonies in the rinsing technique is lower than swab technique so the results found are rinsing techniques more effective from swab techniques. 


\section{Acknowledgment}

We are very grateful for all parties involved in this research.

\section{Conflict of Interest}

The authors report no conflict of interest.

\section{References}

1. Suleh MM, Wowor VNS, Mintjelungan CN. Prevention and control of cross infection in the extraction of teeth in the Dental and Oral Hospital of PSPDG FK UNSRAT. J e-Gigi(eG) 2015;3: 587-588. (In Indonesia)

2. Kosutic D, Uglesic V, Perkovic D, et al. Preoperative antiseptics in clean/contaminated maxillofacial and oral surgery: prospective randomized study'. Int J Oral \& Maxillofac Surg 2009;38: 160-162.

3. Mervrayano J, Rahmatini, Bahar E. Comparison of the effectiveness of mouthwash containing chlorhexidine and povidone iodine against streptococus mutans. J Kesehatan Andalas 2015;1: 169. (In Indonesia)

4. Johnson NR, Kazoulis A, Bobinskas AM. Bacterial comparison of preoperative rinsing and swabbing for oral surgery using $0.2 \%$ chlorhexidine. J Investig \& Clin Dent 2015;6: 193-194.
5. Scannapieco FA, Yu J, Raghavendran K. A randomized trial of chlorhexidine gluconate on oral bacterial pathogens in mechanically ventilated patients. 2009;13: 4 .

6. Cappucino JG, Welsh C. Microbiology: a laboratory manual. 11th ed. Essex: Pearson Education Limited; 2017. p. 20-33.

7. Patabang WA, Leman MA, Maryono J. The difference in the growth of the number of oral bacterial colonies before and after using mouthwash containing chlorhexidine. J Ilmiah Farmasi 2016;5: 27-28. (In Indonesia)

8. Marsh PD, Martin MV. Oral microbiology Fifth Edition. London New York: Elsevier; 2009. p. 8.

9. Riza A, Siregar IB, Isnandar, et al. Comparison of effectiveness disinfection of $2 \%$ glutaraldehyde and $4.8 \%$ chloroxylenol on tooth extraction instruments in the Department of Oral Maxillofacial and Surgery, Faculty of Dentistry, University of North Sumatera. J Dentomaxillofac Sci 2018;3: 169-171.

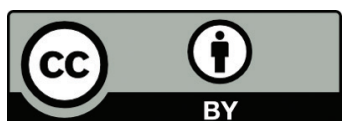

This work is licensed under a Creative Commons Attribution 